\title{
Molecular Characterization of a Somatically Mutated Anti-DNA Antibody Bearing Two Systemic Lupus Erythematosus-related Idiotypes
}

\author{
Anne Davidson, Audrey Manheimer-Lory, Cynthia Aranow, Robert Peterson, Noreen Hannigan, and Betty Diamond \\ Departments of Microbiology and Immunology, and Medicine, Albert Einstein College of Medicine, Bronx, New York 10461
}

\begin{abstract}
We report the molecular characterization of $2 \mathrm{A4}$, an IgG, DNA-binding antibody bearing the $3 I$ and $F 4$ idiotypes which are associated with anti-DNA antibodies in serum of patients with systemic lupus erythematosus (SLE). The antibody is produced by an EBV-transformed B cell line derived from a patient with multiple myeloma whose myeloma protein is also an IgG, 3I-reactive, F4-reactive, DNA-binding immunoglobulin, although the $2 \mathrm{A4}$ antibody does not itself represent the myeloma protein. The $2 A 4$ heavy chain is encoded by a $V_{H} 4$ gene, a D-D gene fusion and the $J_{H^{6}}$ gene; the light chain is derived from a $V_{k} 1$ gene and the $J_{k} 2$ gene. This is the first human antibody shown to have a CDR3 encoded by a D-D fusion. DNA sequence analysis of the $2 A 4 V_{H}$ gene together with a Southern blot of genomic DNA probed with a $2 A 4$ $\mathbf{V}_{\mathbf{H}^{-}}$-specific oligonucleotide strongly suggest it to be somatically mutated. The data previde evidence that human autoantibodies can be products of somatically mutated genes and suggest that the $2 \mathrm{~A} 4$ antibody may reflect the selective pressure of antigen. (J. Clin. Invest. 1990. 85:1401-1409.) anti-DNA antibody - Epstein-Barr virus-transformed B cell • somatic mutation - systemic lupus erythematosus
\end{abstract}

\section{Introduction}

Many sources are contributing to our understanding of the molecular genetic origins of human autoantibodies. Although the data are not yet conclusive, it appears that the germline immunoglobulin genes used to encode autoantibodies exist in nonautoimmune individuals and can be used to encode nonself-reactive antibodies (1-4). There is still considerable controversy, however, whether autoantibodies are encoded by unmutated germ line genes and produced by circulating B cells that are not specifically activated by antigen $(2,5-8)$, or whether they are encoded by somatically mutated genes which because of increased affinity for antigen are selected during a secondary B cell response (9-11).

We have been studying anti-DNA antibodies, the serologic hallmark of the disease systemic lupus erythematosus (SLE). ${ }^{1}$

\section{This study was presented in part at the FASEB meeting, New Orleans, LA, March 1989 (Abstract 2607). \\ Address reprint requests to Dr. Diamond, Department of Microbi- ology and Immunology, 1300 Morris Park Avenue, Bronx, NY 10461. \\ Received for publication 29 June 1989 and in revised form 9 Jan- uary 1990.}

1. Abbreviations used in this paper: $\mathrm{CDR}$, complementarity-determining region; FR, framework region; SLE, systemic lupus erythematosus.

J. Clin. Invest.

(c) The American Society for Clinical Investigation, Inc.

0021-9738/90/05/1401/09 \$2.00

Volume 85, May 1990, 1401-1409
Analyses of anti-DNA antibodies from genetically unrelated SLE patients have demonstrated the existence of cross-reactive idiotypes (12-14) suggesting that anti-DNA antibodies are encoded by a restricted set of germline genes. The heterogeneity of serum anti-DNA antibodies precludes a detailed study of their fine specificity or of the amino acid sequences of their variable regions. Without such information no conclusions can be drawn with respect to the relationship of high-affinity DNA-binding antibodies to germline variable region genes. We have previously exploited the availability of human myeloma proteins to explore the role of somatic mutation in the production of anti-DNA antibodies $(11,15)$. We examined myeloma proteins for the expression of two anti-DNA-associated idiotypes, $3 \mathrm{I}$ and $\mathrm{F} 4$. The $3 \mathrm{I}$ idiotype is present on $\kappa$ light chains of anti-DNA antibodies, and the F4 idiotype is present on the heavy chain variable region. We found that within the 3I idiotype system, DNA binding is associated predominantly with IgG antibodies and is a feature of only a very few IgM antibodies (15). We further found that coexpression of 3I and F4 reactivity is highly associated with DNA binding. Although $3 \mathrm{I}$ reactivity is present on both IgM and IgG antibodies, F4 reactivity is almost exclusively found on IgG antibodies (11).

Hybridoma anti-DNA antibodies have been obtained from fusions of peripheral blood lymphocytes of SLE patients to a human drug-marked myeloma cell line (16-18). The antibodies generated in this fashion are almost exclusively of the IgM isotype. Although these appear to reflect the unmutated germ line gene sequences, they are not representative of the high-affinity IgG antibodies that are characteristically found in lupus sera and are presumed to represent the pathogenic autoantibodies $(19,20)$. We decided to transform bone marrow B cells from a patient with a 3I- and F4-reactive, DNA-binding IgG myeloma in the hope of obtaining a B cell line producing a 3I- and F4-reactive anti-DNA antibody. Previous studies have shown that patients with myeloma possess in their bone marrow $B$ cells at various stages of maturation expressing the idiotype of the myeloma protein $(21,22)$. These B cells may be precursors of the malignant plasma cell before expression of a fully malignant phenotype $(21,23)$ or they may be related to the malignant plasma cell through an idiotypic network (22). Using EBV transformation to immortalize the cells, we obtained both 3I-reactive IgM and IgG-producing lines and 3Iand F4-reactive, IgG-producing lines. Some of the lines were DNA binding.

We now report the cloning and sequencing of the heavy and light chain genes of $2 \mathrm{~A} 4$, a $3 \mathrm{I}-$ and F4-reactive line that encodes a DNA-binding IgG antibody that is not identical to the myeloma protein. It uses a member of the $V_{H} 4$ family, DLR3-DIR2 and $\mathrm{J}_{\mathrm{H}} 6$ to encode the heavy chain $\mathrm{V}$ region and a $V_{K 1}$ and $J_{K 2}$ to encode the light chain $V$ region. Both the heavy and light chain $\mathrm{V}$ region sequences show many differences from the most homologous germline genes yet identified. Whereas the germ line $V_{H}$ from which the $2 A 4 V_{H}$ is most likely derived is already cloned and sequenced (24), to date no 
germline $V_{K}$ sequence bearing sufficient homology to the gene that encodes the 2A4 light chain has been reported. A high replacement/silent mutation ratio in the heavy chain complementarity-determining regions (CDRs), compared with that in the framework regions (FRs), suggests that the 2A4 antibody has arisen in an antigen-selected response.

\section{Methods}

Generation of $E B V$-transformed B cell lines. Lymphocytes were obtained by Ficoll-Hypaque centrifugation of bone marrow cells of patient Hic with multiple myeloma. The patient's DNA-binding myeloma protein is an IgG antibody and expresses both the F4 and the $3 \mathrm{I}$ idiotypic determinants.

Lymphocytes $10^{6} / \mathrm{ml}$ were suspended in RPMI media (Mediatech, Washington, DC), supplemented with $10 \%$ FCS (Hyclone Laboratories, Logan, UT), $1 \%$ glutamine, $1 \%$ penicillin streptomycin, $1 \%$ sodium pyruvate, $1 \%$ nonessential amino acids, and $0.01 \mathrm{M}$ Hepes. Aliquots of $1 \mathrm{ml}$ were transformed with $200 \mu \mathrm{l}$ of supernatant from a dense culture of the EBV-secreting marmoset cell line B95.8 (American Type Culture Collection, Rockville, MD) and $0.5 \mu \mathrm{g}$ of cyclosporin A. After 2 wk, bulk culture supernatants were screened by ELISA for idiotype expression. Plates (Probind, Falcon Labware, Lincoln Park, $\mathrm{NJ})$ coated with pure F4 or $3 \mathrm{I}$ anti-idiotype at a concentration of 10 $\mu \mathrm{g} / \mathrm{ml}$ in PBS $\left(0.02 \mathrm{M} \mathrm{NaPO}_{4}, 0.15 \mathrm{M} \mathrm{NaCl}, \mathrm{pH} 7.2\right)$ at $4^{\circ} \mathrm{C}$ overnight, were washed and blocked with PBS containing 5\% FCS, 3\% BSA for 1 $\mathrm{h}$ and then incubated with $100 \mu \mathrm{l}$ culture supernatant at $37^{\circ} \mathrm{C}$ for $1 \mathrm{~h}$. Plates were washed and incubated with peroxidase conjugated affinity-purified goat anti-human immunoglobulins (Cappel Laboratories, Westchester, PA) at a 1/750 dilution in PBS $1 \%$ BSA followed by 2,2'-azino-di-[3-ethylbenzthiazoline sulfonate (6)] substrate (Kirkegaard \& Perry Laboratories, Inc., Gaithersburg, MD). Purified idiotype-positive myeloma proteins and media alone were used as controls. Bulk cultures expressing either the F4 or $3 \mathrm{I}$ idiotype were then subcloned into round-bottom plates (Corning Glass Works, Corning, NY) in medium supplemented with $10 \%$ FCS and $20 \%$ supernatant from the murine macrophage cell line J774.2 (25) at a dilution such that less than one-third of the wells yielded viable clones. Clones were rescreened for idiotype expression.

Assay for Ig isotype. Clonal lines were screened for immunoglobulin isotype by ELISA. Plates (Probind) were coated overnight at $4^{\circ} \mathrm{C}$ with each of goat anti-human IgM, IgG, and IgA (Meloy Laboratories, Inc., Springfield, VA) at a concentration of $10 \mu \mathrm{g} / \mathrm{ml}$ in PBS. Plates were blocked with PBS containing 5\% FCS/3\% BSA and incubated with cell supernatant followed by peroxidase-conjugated goat antihuman immunoglobulin (Cappel Laboratories) at a concentration of $1 / 750$ in PBS/1\% BSA and then 2,2'-azino-di-[3-ethylbenzthiazoline sulfonate (6)] substrate. Myeloma proteins of known isotype and media alone were used as controls.

Assays for DNA binding. Cell lines were grown in serum-free medium and tested for DNA binding by filter assay (Millipore Corp., Bedford, MA). Supernatant from a serum-free culture was quantitated for IgG content by standardization with known quantities of purified IgG. For the filter assay IgG was incubated for $30 \mathrm{~min}$ at $37^{\circ}$ with nick-translated ${ }^{32} \mathrm{P}$-labeled DNA made double-stranded by passage through a nitrocellulose filter (HAWP 45, Millipore Corp.). The mixture was then passed through a nitrocellulose filter, and the filter was assayed for bound radioactivity.

Cloning and sequencing of $2 A 4$ heavy and light chain genes. RNA was extracted from $10^{9}$ cells of the $2 \mathrm{~A} 4$ clone and the 4B4 clone by standard techniques using $4 \mathrm{M}$ guanidium thiocyanate followed by layering on a $5.7 \mathrm{M}$ cesium chloride gradient. Polyadenylated RNA was purified on an oligo-dT column (Collaborative Research Inc., Bedford, MA). Preliminary mRNA sequencing of heavy and light chains was performed using the dideoxy termination method (26). The $V_{H}$ was found to belong to the $V_{H} 4$ family and the $V_{K}$ to the $V_{K} 1$ family. A cDNA library of each clone was generated in $\lambda$ gt 10 using $5^{\prime}$ $\mathrm{C}_{\gamma}$ and $\mathrm{C}_{\kappa}$ probes to generate the first strand cDNA. $5 \times 10^{5}$ plaques from each library were screened with a $5^{\prime} \mathrm{V}_{\mathrm{H}} 4$-specific probe (obtained from Drs. J. Berman and F. Alt, Columbia University) (27) and with an oligonucleotide probe directed to a conserved 20-basepair region of the leader sequence of the $V_{K} 1$ gene family 5 ' GCAGGAGCCCCAGGAGCTGA 3' (28). Appropriate clones were plaque purified and subcloned into pGEM vectors (Promega Biotec, Madison, WI.) for sequencing. Dideoxy chain termination sequencing of both strands was performed using a standard kit (Sequenase, United States Biochemical Corp., Cleveland, $\mathrm{OH}$ ).

Southern blot analysis. Cells from wells positive for idiotype expression were screened for clonality by Southern blotting with $J_{K}$ and $\mathrm{J}_{\mathrm{H}}$ probes. Genomic DNA was extracted from cells. $10 \mu \mathrm{g}$ of DNA was digested with EcoRI and Bam HI restriction enzymes and electrophoresed at $50 \mathrm{~V}$ overnight. DNA was blotted onto nitrocellulose and probed overnight at $42^{\circ} \mathrm{C}$ with human $\mathrm{J}_{\mathrm{H}}$ (obtained from Dr. F. Alt) and $J_{K}$ probes (obtained from Dr. P. Leder, Harvard University) radiolabeled with ${ }^{32} \mathrm{P}$ by nick-translation. Blots were then washed in $2 \times$ SSC $1 \%$ SDS at $68^{\circ} \mathrm{C}$ and autoradiographed. Those cloned cell lines showing no more than two rearrangements of both $\mathrm{J}_{\mathrm{H}}$ and $\mathrm{J}_{\mathrm{K}}$ loci were selected for further characterization.

Southern blot analysis using oligonucleotide probes. To determine if the heavy chain-variable region genes utilized by the cell line $2 \mathrm{~A} 4$ is a somatic mutant of germline genes, Southern analysis using an oligonucleotide probe to the CDR2 region of the heavy chain 5' ATCGATACCAGTGGGAACAT $3^{\prime}$ was performed. Briefly, 30-50 $\mu \mathrm{g}$ of genomic DNA prepared from Hic bone marrow or from the cell line 2A4 was digested with BamHI. DNA was fractionated on a $0.8 \%$ agarose gel. After electrophoresis, DNA was transferred from the gel to gene screen (New England Nuclear Research Products, Boston, MA) overnight. Subsequently, filters were baked, pretreated, with $5 \times$ SSC, 20 $\mathrm{mM} \mathrm{PO}, 7 \%$ SDS, $10 \times$ Denhardt's, $1 \mathrm{mg} / \mathrm{ml}$ salmon sperm DNA, hybridized (12.5\% dextran sulfate) to the oligonucleotide probe at $\mathrm{Tm}-5^{\circ} \mathrm{C}$, washed $1 \mathrm{~h}$ in $3 \times \mathrm{SSC}, 20 \mathrm{mM} \mathrm{PO}, 5 \%$ SDS, $10 \times$ Denhardt's followed by $1 \mathrm{~h}$ in $1 \times$ SSC $1 \%$ SDS, and autoradiographed as previously described (29).

\section{Results}

EBV-transformed B cell lines were readily obtained. The characteristics of these cells lines will be reported elsewhere. Several 3I- and F4-reactive clones were obtained. Although some of these lines represent independent clones as demonstrated by Southern blot analysis, not all represent independent clones as bulk cultures were maintained several weeks before cloning. The 2A4 cell line was selected for molecular study because of expression of both the $3 \mathrm{I}$ and the F4 idiotype, DNA binding, and IgG isotype, (Tables I and II) all characteristics of pathogenic antibodies found in serum and kidneys of SLE patients $(19,20)$. Clonality of the line was confirmed by Southern blotting using $J_{H}$ and $J_{K}$ probes to identify immunoglobulin gene rearrangements. Two heavy chain gene rearrangements and two light chain gene rearrangements were identified (Fig. 1). A second 3I- and F4-reactive DNA IgG binding clone, 4B4, was also analyzed. It had identical $\mathbf{J}_{H}$ and $\mathbf{J}_{\mathbf{k}}$ rearrangements. These rearrangements both differ from the immunoglobulin gene rearrangements that are responsible for the myeloma protein (data not shown) so the 2A4/4B4 antibody does not represent the Hic myeloma protein.

Cloning of heavy and light chain genes. Preliminary mRNA sequencing of $2 \mathrm{~A} 4$ revealed that the $2 \mathrm{~A} 4$ heavy chain is encoded by a member of the $\mathrm{V}_{\mathrm{H} 4}$ gene family and that the light chain is encoded by a member of the $V_{K 1}$ family. Probes specific for these gene families were therefore used to screen cDNA libraries from the 2A4 and 4B4 lines. The sequence of the entire heavy and light chain variable regions including the leader sequence of each line was obtained. Inasmuch as the 
Table I. 2A4 Expresses $3 I$ and F4 Reactivity

\begin{tabular}{lcc}
\hline & \multicolumn{3}{c}{ OD 405 } \\
\cline { 2 - 3 } & 3I & F4 \\
\hline Negative control & $0.140 \pm 0.021$ & $0.136 \pm 0.053$ \\
Positive control & $0.620 \pm 0.219$ & $0.391 \pm 0.141$ \\
2A4 & $0.448 \pm 0.016$ & $0.442 \pm 0.013$
\end{tabular}

$1 \mu \mathrm{g}$ of $3 \mathrm{I}$ or $\mathrm{F} 4$ antibody was adsorbed to microtiter wells. $2 \mathrm{~A} 4$ antibody or purified $\mathrm{IgG}$ myeloma proteins $(1 \mu \mathrm{g} / \mathrm{ml})\left(3 \mathrm{I}^{-} \mathrm{F}^{-}\right.$and $3 \mathrm{I}^{+}$

$\mathrm{F}^{+}$) were added, followed by antibody to human Ig and substrate.

sequences obtained from the two lines were identical, we will discuss the 2A4 line. The 2A4 sequences were compared with known $V_{H 4}$ and $V_{K 1}$ germline gene sequences. Nine germline sequences have thus far been reported for the $\mathrm{V}_{\mathrm{H}} 4$ gene family $(24,27,30)$. The $2 \mathrm{~A} 4$ heavy chain is most homologous to the V71-2 germline gene reported by Lee et al. (24) (Fig. 2). Analysis of the ratio of replacement to silent mutations is shown in Table III. 15 base changes occur in FRs; 5 are replacement mutations and 10 are silent. All nine mutations in CDRs are replacement mutations. The derived protein sequence for the $2 \mathrm{~A} 4$ heavy chain is shown in Fig. 3. The heavy chain variable region differs from the derived V71-2 sequence by 12 amino acids, four of which represent nonconservative changes resulting in a net accumulation of two positive charges.

The $\mathrm{D}$ region of $2 \mathrm{~A} 4$ appears to be a fusion of two human $D$ region genes, DLR3 and a DIR gene upstream of DM2. The DIR gene is a member of a newly described $D$ gene family. This family is characterized by 12-23 spacers rather than the usual 12-12 D region spacers. These unusual spacers may allow for D-D joining (31). 2A4 has 15 of 18 nucleotides in common with the DLR3 and 16 of 20 nucleotides in common with the DIR2 gene. The 2A4 D region has an initial 5 nucleotides that may represent $\mathrm{N}$ sequences, 18 nucleotides from DLR3, an inserted cytosine, then 20 nucleotides from the DIR2 gene followed by another six bases that may represent $N$ sequences (Fig. 4).

The DLR3 sequence has base changes leading to the substitution of a methionine for a valine, a glycine for a valine,

Table II. 2 A4 Binds DNA by Millipore Filter Assay

\begin{tabular}{lcc}
\hline & Dilution & $\begin{array}{c}\text { Bound } \\
\text { radioactivity }\end{array}$ \\
\hline $2.5 \mu \mathrm{g} / \mathrm{ml}$ normal IgG & & $c p m$ \\
& $1: 1$ & 277 \\
$2.5 \mu \mathrm{g} / \mathrm{ml}$ 2A4 IgG & $1: 2$ & 395 \\
& $1: 5$ & 394 \\
Medium alone & $1: 1$ & 1,612 \\
& $1: 2$ & 1,263 \\
& $1: 5$ & 1,153 \\
\end{tabular}

2A4 supernatant or purified normal human IgG diluted in serumfree media was incubated with ${ }^{32} \mathrm{P}$-labeled double-stranded DNA and passed through a nitrocellulose filter. Bound radioactivity represents anti-DNA activity.

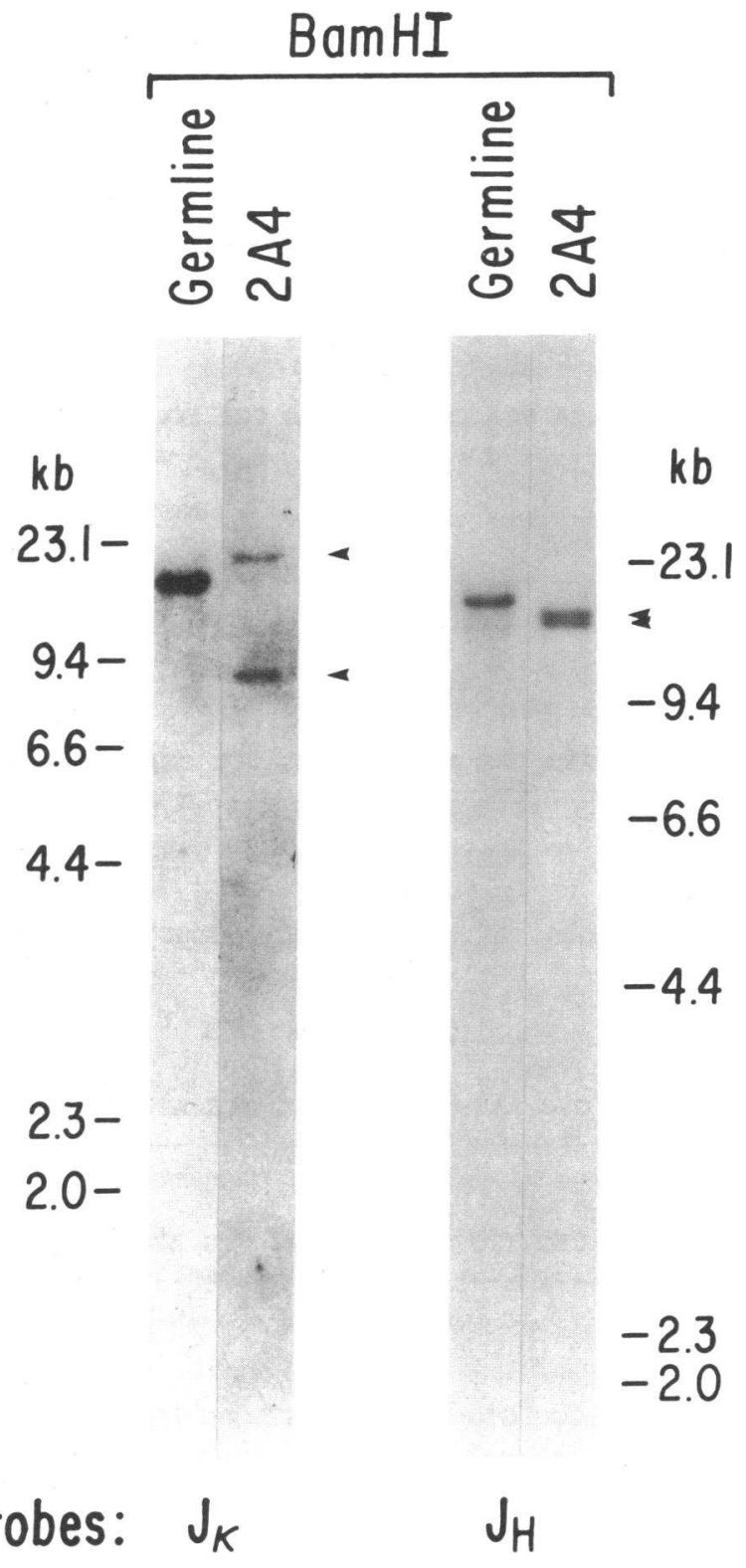

Figure 1. Southern analysis of germline DNA and heavy and light chain rearrangements of the 2A4 DNA digested with BamHI and probed with $J_{H}$ and $J_{K}$ probes. There are two heavy chain and two light chain rearrangements identified by the arrows. Germline $J_{K}$ is $12 \mathrm{~kb}$ and germline $J_{H}$ is $17 \mathrm{~kb}$. Samples were electrophoresed on two different gels.

and a glutamic acid for a valine. These substitutions result in the net accumulation of one negative charge more than in the sequence encoded by the DLR 3 germline sequence. The insertion of a cytosine as the first base in the DIR2 sequence leads to the substitution of an arginine for a glycine. In addition, there is a substitution downstream replacing a glutamine with a lysine and thus generating a net of two positive charges in the second half of the $D$ region.

In an attempt to prove that the $2 \mathrm{~A} 4$ antibody is indeed the product of somatic mutation, we synthesized an oligonucleotide probe identical to the CDR2 of the $2 A 4$ heavy chain. This oligonucleotide was used to probe DNA from the $2 \mathrm{~A} 4$ cell line and Hic bone marrow genomic DNA. The oligonucleotide 


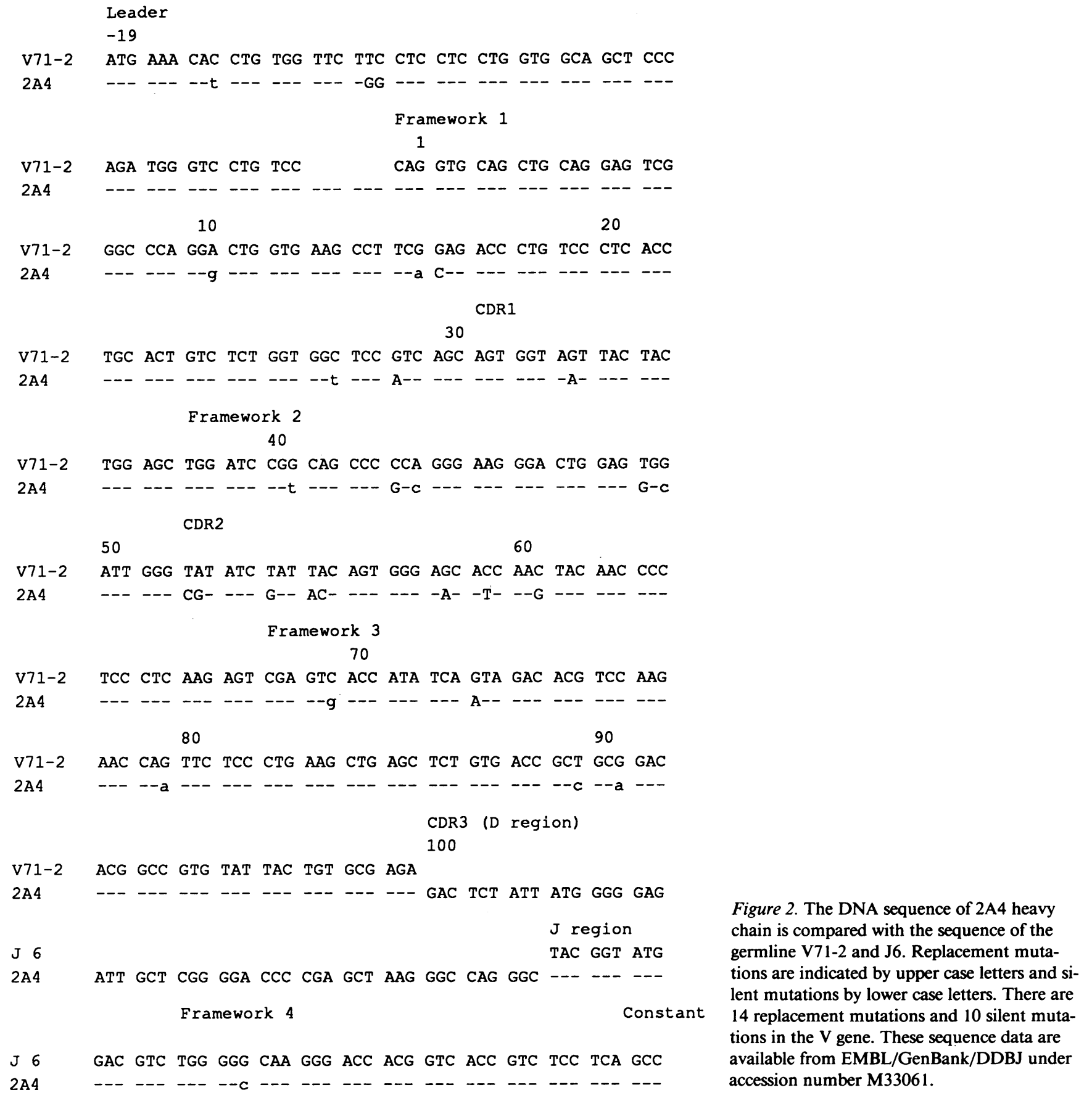

hybridizes to a band representing the rearranged $\mathrm{V}_{\mathrm{H}} 4$ gene from the 2A4 cell line, but does not hybridize to any band representing a $\mathrm{V}_{\mathrm{H}} 4$ germ line gene in the Southern blot of the patient's own (Hic) genomic DNA (Fig. 5). The heavy chain CDR2 must therefore contain sequences that vary from germline sequences present in the patient's own DNA.

For the $V_{k} 1$ gene family, 15 of approximately 20-30 germline sequences have been reported of which nine are functional genes $(28,32)$. The $2 \mathrm{~A} 4$ light chain gene has 45 base differences from the Hk101 gene and 44 from the Hk 102 gene (Fig. 6). The human $V_{K 1}$ gene family is a large family and from comparison of the $2 \mathrm{~A} 4$ sequence to known $\mathrm{V}_{\mathrm{k} 1}$ sequences it appears unlikely that the appropriate germline gene has yet been isolated and sequenced. Thus an analysis of replacement and silent mutations cannot be performed for the light chain of $2 \mathrm{~A} 4$. However, the $\mathrm{J}$ segment sequence of $2 \mathrm{~A} 4$ differs from germline $J_{K} 2$ by four base changes resulting in two replacement and two silent mutations.

\section{Discussion}

The B cell response to antigen is a complex one. The primary response to antigen is mediated by antibodies of the IgM iso- 


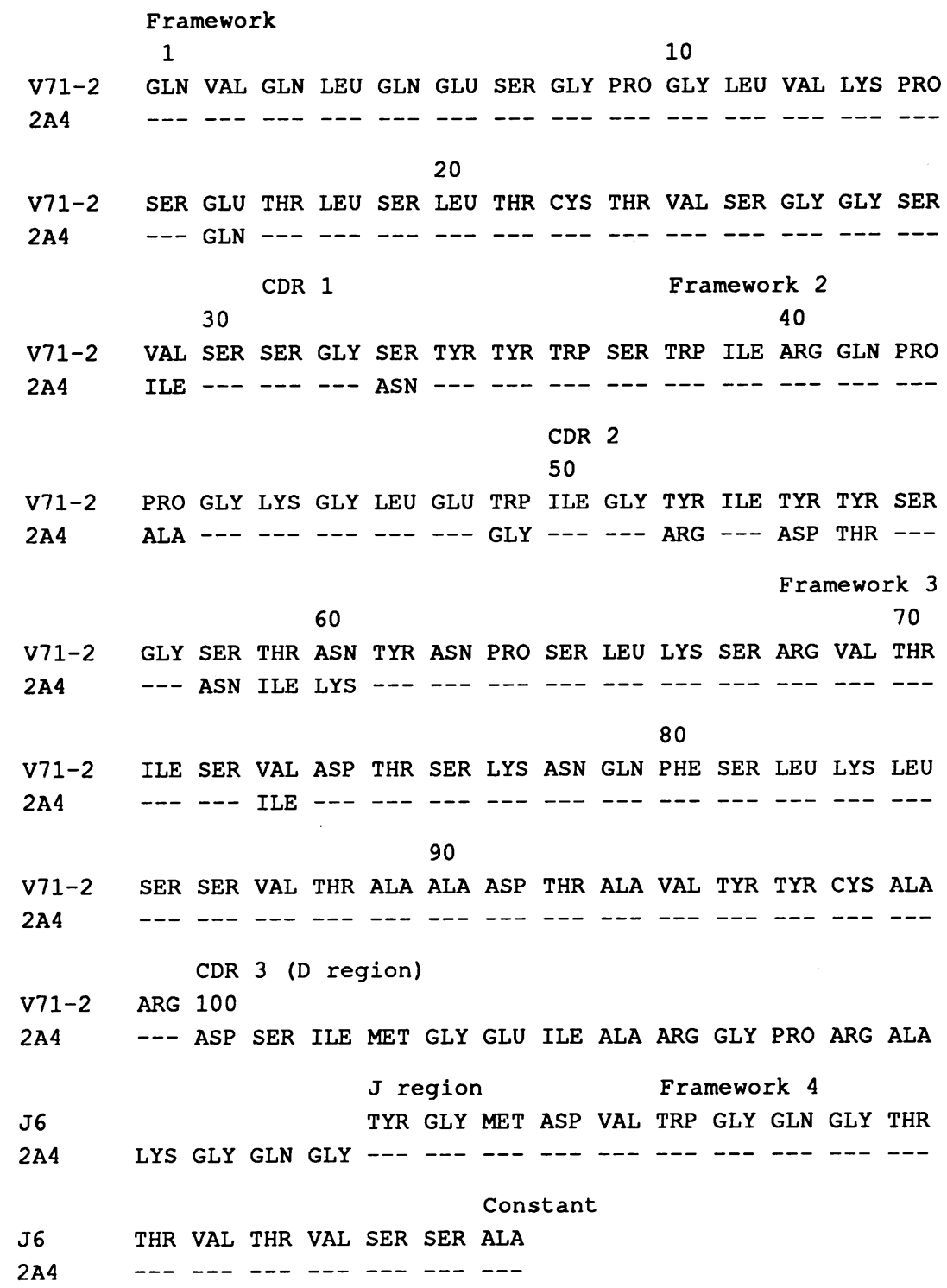

Figure 3. The derived protein sequences of the V71-2 and 2A4 heavy chains are compared. These sequence data are available from EMBL/GenBank/ DDBJ under accession number M33060. type that are present in the preimmune repertoire and generally reflect germline gene sequences. As the immune response develops and B cells interact with both antigen and activated $T$ helper cells, B cells with higher affinity for antigen are generated by somatic mutation and are selected by antigen for clonal expansion (33). This hypermutation process is most frequently seen in IgG antibodies. It has long been debated whether autoantibodies found in autoimmune diseases are the products of nonspecific B cell activation and therefore reflect the low-affinity, unmutated IgM antibodies found in the preimmune repertoire (8) or whether they arise in the course of an immune response to a specific antigen and reflect the higher-affinity mutated, IgG antibodies of the secondary response (11). Molecular analysis of autoantibodies is one approach to resolving this problem.

We have previously demonstrated that anti-DNA antibodies found in patients with SLE share cross-reactive idiotypes $(11,12)$. This observation suggests that these antibodies are encoded by a restricted number of germline genes. The 31 monoclonal anti-idiotype recognizes $\mathrm{K}$ chains of anti-DNA antibodies in $85 \%$ of SLE patients with anti-DNA activity (34). The F4 anti-idiotype recognizes heavy chains on antiDNA antibodies in $60 \%$ of SLE patients. Studies of myeloma proteins and SLE sera have revealed that coexpression of both 3I and F4 idiotypes is highly associated with DNA binding activity (11). Furthermore, our studies of myeloma proteins revealed that DNA binding is present almost exclusively on antibodies of the IgG isotype and is associated in the 3I idiotype system with cationic immunoglobulins (15). These studies have led us to hypothesize that DNA binding activity may reflect the accumulation of somatic mutations that occurs after exposure to antigen and $\mathrm{T}$ cell factors. For this reason, we wished to obtain the sequence of DNA binding antibodies bearing SLE related idiotypes and compare them with known germline gene sequences.

Myeloma proteins frequently display autoreactivity. In addition, they often express autoantibody associated idiotypes. It is not known why the repertoire of malignant B cells is skewed towards autoreactivity compared with the repertoire of serum immunoglobulin. It is also not understood why individuals 


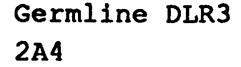

AG CAT ATT GTG GTG GTG ATT GCTATTCC

G-C TC- --- A-- -G- -A- - - -

$\mathrm{N}$ sequence

$$
\text { CACCCAGGA GGC CCC AGA GCT CAG GGC GCC CCG }
$$




\begin{tabular}{|c|c|c|c|c|c|c|c|c|c|c|c|c|c|c|}
\hline & $\begin{array}{l}\text { Lead } \\
-19\end{array}$ & & & & & & & & & & & & & \\
\hline $\mathrm{Hk} 101$ & ATG & GAC & ATG & AGG & GTC & $\mathrm{CCC}$ & $\mathrm{GCT}$ & CAG & CTC & CTG & GGG & CTC & CTG & CTG \\
\hline $2 \mathrm{~A} 4$ & -- & --- & --- & --- & --- & --- & --- & --- & -- & -- & --- & --- & -- & --- \\
\hline $\mathrm{Hk} 102$ & --- & --- & --- & -- & -- & --- & --- & --- & --- & --- & --- & --- & --- & --- \\
\hline & & & & & & & & & $\begin{array}{l}\text { Frame } \\
1\end{array}$ & work 1 & & & & \\
\hline $\mathrm{Hk} 101$ & CTC & TGT & TTC & $\mathrm{CCA}$ & GGT & GCC & $\mathrm{AGA}$ & TGT & GAC & ATC & CAG & ATG & $\mathrm{ACC}$ & CAG \\
\hline $2 \mathrm{~A} 4$ & -- & $--G$ & C-- & $-G-$ & A-- & -- & $\cdots$ & --- & -- & C-- & A-- & --- & --- & --- \\
\hline HK102 & --- & $--G$ & --- & --- & --- & --- & $-A-$ & -- & -- & --- & -- & --- & --- & --- \\
\hline & & & & 10 & & & & & & & & . & & 20 \\
\hline $\mathrm{Hk} 101$ & $\mathrm{TCT}$ & $\mathrm{CCA}$ & TCC & TCA & CTG & TCT & $\mathrm{GCA}$ & $\mathrm{TCT}$ & GTA & GGA & GAC & AGA & GTC & ACC \\
\hline $2 \mathrm{~A} 4$ & --- & --- & $--\mathbf{A}$ & $--C$ & --- & $\mathrm{C}--$ & --- & --- & $--T$ & --- & --- & $-\mathrm{C}-$ & --- & --- \\
\hline HK102 & --- & $--T$ & --- & $A-C$ & --- & --- & --- & --- & --- & -- & --- & --- & -- & --- \\
\hline & & & CDR1 & & & & & & & & & & & \\
\hline & & & & & & & & & & 30 & & & & \\
\hline Hk101 & ATC & $\mathrm{ACT}$ & TGT & CGG & GCG & AGG & CAG & GGT & ATT & AGC & AGC & TGG & TTA & GCC \\
\hline $2 \mathrm{~A} 4$ & --- & --- & $--C$ & --- & $--A$ & $--T$ & --- & $A-C$ & --- & $-A-$ & $--G$ & $-\mathrm{TT}$ & --- & AAT \\
\hline HK102 & --- & --- & $--C$ & --- & $--c$ & $--T$ & --- & A-- & --- & $--T$ & --- & --- & $--G$ & --- \\
\hline & Fram & work 2 & & & & & & & & & & & & \\
\hline & & & & & & 40 & & & & & & & & \\
\hline $\mathrm{Hk} 101$ & TGG & TAT & CAG & CAG & AAA & $\mathrm{CCA}$ & GAG & $A A A$ & GCC & $\mathrm{CCT}$ & AAG & TCC & CTG & ATC \\
\hline $2 \mathrm{~A} 4$ & --- & --- & --- & --- & --- & --- & $-G-$ & --- & --- & --- & --- & $\mathrm{CT}-$ & --- & --- \\
\hline HK102 & --- & --- & --- & --- & -- & -- & $-G-$ & --- & --- & --- & --- & $\mathrm{CT}-$ & --- & -- \\
\hline & & CDR2 & & & & & & Fram & work 3 & & & & & \\
\hline & & 50 & & & & & & & & & & 60 & & \\
\hline $\mathrm{Hk} 101$ & TAT & GCT & $\mathrm{GCA}$ & $\mathrm{TCC}$ & AGT & TTG & $\mathrm{CAA}$ & AGT & GGG & GTC & $\mathrm{CCA}$ & $\mathrm{TCA}$ & AGG & TTC \\
\hline $2 \mathrm{~A} 4$ & --- & $-G-$ & --- & -- & --- & --- & --- & --- & --- & $\mathrm{T}--$ & $\mathrm{T}-\mathrm{T}$ & --- & --- & $--T$ \\
\hline HK102 & --- & $-\mathrm{A}^{-}$ & $--C$ & --- & --- & --- & G-- & --- & --- & -- & --- & --- & --- & --- \\
\hline & & & & & & & & 70 & & & & & & \\
\hline $\mathrm{Hk} 101$ & AGC & GGC & AGT & GGA & $\mathrm{TCT}$ & GGG & $\mathrm{ACA}$ & GAT & TTC & $\mathrm{ACT}$ & СтC & $\mathrm{ACC}$ & ATC & AGC \\
\hline $2 \mathrm{~A} 4$ & $--T$ & --- & -- & -- & --- & --- & --- & $--G$ & --- & --- & --- & --- & --- & $--A$ \\
\hline HK102 & --- & --- & --- & --- & --- & --- & --- & $--A$ & --- & --- & --- & -- & & --- \\
\hline & & & & & & & & & & & & & $\mathrm{CDR} 3$ & \\
\hline & & & & 80 & & & & & & & & & & 90 \\
\hline $\mathrm{Hk} 101$ & AGC & CTG & CAG & $\mathrm{CCT}$ & GAA & GAT & TTT & GCA & $\mathrm{ACT}$ & TAT & TAC & TGC & CAA & $\mathrm{CAG}$ \\
\hline $2 \mathrm{~A} 4$ & $--T$ & --- & $--A$ & --- & $--G$ & --- & --- & --- & --- & $--C$ & --- & $--T$ & -- & $--A$ \\
\hline HK102 & --- & --- & --- & --- & $--\mathrm{T}$ & $-\cdots$ & --- & --- & --- & --- & --- & --- & --- & --- \\
\hline & & & & & & & & & Frame & work & & & & \\
\hline & & & & & & $95 \mathrm{~A}$ & J2 & & & & 100 & & & \\
\hline $\mathrm{Hk} 101$ & TAT & AAT & AGT & TAC & $\mathrm{CCT}$ & & TAC & $\mathrm{ACT}$ & TTT & GGC & CAG & GGG & $\mathrm{ACC}$ & AAG \\
\hline $2 \mathrm{~A} 4$ & AG- & $\mathrm{T}--$ & --- & $\mathrm{AC}-$ & --- & CCG & G-- & --- & --- & --- & --- & --- & --- & --- \\
\hline HK102 & --- & --- & --- & $--T$ & T-- & & & & & & & & & \\
\hline & & & & & 108 & & & & & & & & & \\
\hline $\mathrm{Hk} 101$ & CTG & GAG & ATC & $A A A$ & CGT & & & & & & & & & \\
\hline $2 \mathrm{~A} 4$ & G-- & $--a$ & --- & --- & $--a$ & & & & & & & & & \\
\hline
\end{tabular}

Figure 6. 2A4 light chain DNA sequence compared with HK101 and HK102 genes $(28,32)$. There are 45 differences from HK101 and 44 from HK102. These sequence data are available from EMBL/GenBank/DDBJ under accession number M33060.

variable region gene locus $(27,28)$. There may be little polymorphism among individuals $(27,36)$. The human $\mathrm{V}_{\mathrm{H} 4}$ gene family is a relatively small family with approximately 6-10 different members as demonstrated by restriction enzyme analysis. Nine different $\mathrm{V}_{\mathrm{H}} 4$ germline genes, sequenced from two individuals, are described in the literature $(24,27)$. Analy- sis of the Hic and 2A4 genomic Southern blots by using a mutant specific oligonucleotide proves that the $2 \mathrm{~A} 4 \mathrm{~V}_{\mathrm{H}}$ gene is somatically mutated as the $2 \mathrm{~A} 4$-specific probe does not hybridize to the patient's own germline DNA. The DNA sequence of the $2 \mathrm{~A} 4 \mathrm{~V}_{\mathrm{H}}$ gene segment is highly homologous to the V 71-2 germline gene (24). There are 24 basepair differ- 
ences of which 10 result in silent mutations. Only replacement mutations are seen in the CDRs, suggesting that these mutations are part of an antigen selected response. Furthermore, these mutations produce a more positively charged variable region consistent with our previous demonstration within the 3I idiotype system that DNA binding is associated with cationic antibodies (1) and that 3I-reactive, F4-reactive DNAbinding antibodies are, in general, cationic (11). The mutations also lead to the substitution of a glutamine for a glutamate in framework 1, an asparagine for a serine in CDR1, an arginine for a tyrosine and an asparagine for a serine in CDR2, a glutamine for a lysine and an arginine for a glycine in CDR3. Arginine can form two hydrogen bonds with guanine in double-stranded DNA and glutamine and asparagine can hydrogen bond to adenine and so, as postulated by Seeman et al. (37), these amino acids may be important in generating antiDNA activity. The $\mathrm{V}_{\mathrm{H}} 4$ gene family has been reported in one other anti-DNA antibody C6B2 (18). This $\mathrm{V}_{\mathrm{H}} 4$ sequence also appears to be encoded by the V71-2 germline gene. It is not known whether the differences between V71-2 and C6B2 represent polymorphisms of the germline gene or whether C6B2 is also encoded by a somatically mutated $V_{H} 4$ gene.

The 2A4 heavy chain possesses an unusually long $\mathrm{D}$ region which is generated by the joining of two distinct $D$ region gene segments. Although DIR genes have been reported in two previous immunoglobulin heavy chain rearrangements (31), to our knowledge this is the first human antibody to be encoded by a D-D fusion. Eilat et al. (38) have shown that $\mathrm{D}$ regions in anti-DNA antibodies may be used out of frame and that they may be mutated to generate arginine residues (38). Sanz and Capra (39) have postulated that murine autoantibodies frequently contain abnormally long $\mathrm{D}$ regions generated by unusual genetic events such as D-D joining or by inverted D regions (39). It may be that similarly unusual $D$ regions may be common in human autoantibodies.

The human $V_{K} 1$ family is a large gene family comprising at least 20 members. Of these, nine potentially functional genes and six pseudogenes have thus far been sequenced. The $2 \mathrm{~A} 4$ light chain is most homologous to the $H_{K 101}$ and $H_{K 102}(28,32)$ genes. However, the many base differences between the $2 \mathrm{~A} 4$ light chain and the $V_{K} 1$ germline sequences suggest that the 2A4 light chain $\mathrm{V}$ region probably derives from a yet uncharacterized germline gene.

The nature of the mutations present in the $2 \mathrm{~A} 4$ antibody suggest that the antibody has been exposed to the selective forces of antigen and perhaps $T$ cells as well. It will be of interest to compare this antibody to one encoded by the unmutated germ line genes to know how the affinity for DNA is changed. Such analyses have been performed in other antibody systems $(33,40)$. Perhaps the analysis of B cell genealogies from a single patient or of a large panel of idiotypic antibodies from a number of patients can help resolve the question of the role of DNA as an antigen in the production of DNA binding antibodies.

\section{Acknowledgment}

We would like to thank Rosalia Cawley for typing the manuscript.

This work was supported by grants AR-32371 and AI-10702 from the National Institutes of Health and grant CA-13330 from the National Cancer Institute to Dr. Diamond and grants from the New York Systemic Lupus Erythematosus Foundation to Dr. Davidson and from the Irvington Institute for Medical Research. Dr. Manheimer-Lory is the recipient of an Arthritis Foundation fellowship.

\section{References}

1. Halpern, R., A. Davidson, A. Lazo, G. Solomon, R. Lahita, and B. Diamond. 1985. Familial systemic lupus erythematosus, presence of a cross-reactive idiotype in healthy family members. J. Clin. Invest. 76:731-736.

2. Naparstek, Y., J. Andre-Schwartz, T. Manser, L. Wysocki, L. Breitman, B. D. Stollar, M. L. Gefter, and R. S. Schwartz. 1986. A single germline $V_{H}$ gene segment of normal $A / J$ mice encodes autoantibodies characteristic of systemic lupus erythematosus. J. Exp. Med. 164:614-626.

3. Dersimonian, H., R. S. Schwartz, K. Barrett, and B. D. Stollar. 1987. Relationship of human variable region heavy chain germline genes to gene encoding anti-DNA autoantibodies. J. Immunol. 139:2496-2501.

4. Datta, S. K., Y. Naparstek, and R. S. Schwartz. 1986. In vitro production of an anti-DNA antibody idiotype by lymphocytes of normal subjects and patients with systemic lupus erythematosus. Clin. Immunol. Immunopathol. 38:302-308.

5. Chen, P. P., M. F. Liu, S. Sinha, and D. Carson. 1988. A 16/6 idiotype positive anti-DNA antibody is encoded by a conserved $V_{H}$ gene with no somatic mutation. Arthritis Rheum. 31:1429-1431.

6. Chen, P. P., F. Goni, S. Fong, F. Jirik, J. H. Vaughan, B. Frangione, and D. A. Carson. 1985. The majority of human monoclonal IgM rheumatoid factors express a primary structure dependent crossreactive idiotype. J. Immunol. 134:3281-3285.

7. Sanz, I., H. Dang, M. Takei, N. Talal, and J. D. Capra. 1988. V sequence of human anti-Sm autoantibody. J. Immunol. 142:883-887.

8. Klinman, D. M., and A. D. Steinberg. 1987. Systemic autoimmune disease arises from polyclonal B cell activation. J. Exp. Med. 165:1755-1760.

9. Behar, S. M., and M. D. Scharff. 1988. Somatic diversification of the $\mathrm{S} 107(\mathrm{~T} 15) \mathrm{V}_{\mathrm{H} 11}$ germline gene that encodes anti-dsDNA antibodies in (NZB/NZW) $F_{1}$ mice. Proc. Natl. Acad. Sci. USA. 85:39703974.

10. Shlomchik, M. J., A. Marshak-Rothstein, C. B. Wolfowitz, T. L. Rothstein, and M. G. Weigert. 1987. The role of clonal selection and somatic mutation in autoimmunity. Nature (Lond.). 328:805811.

11. Davidson, A., A. Smith, J. Katz, J. L. Preud'homme, A. Solomon, and B. Diamond. 1989. A cross-reactive idiotype on anti-DNA antibodies defines a heavy chain determinant present almost exclusively on IgG antibodies. J. Immunol. 143:174-180.

12. Solomon, G., J. Schiffenbauer, H. D. Keiser, and B. Diamond. 1983. Use of monoclonal antibodies to identify shared idiotypes on human antibodies to native DNA from patients with systemic lupus erythematosus. Proc. Natl. Acad. Sci. USA. 80:850-854.

13. Zouali, M., and A. Eyquem. 1985. Idiotype restriction on human autoantibodies to DNA in systemic lupus erythematosus. Immunol. Lett. 7:187-190.

14. Shoenfeld, Y., D. A. Isenberg, J. Rauch, M. P. Madaio, B. D. Stollar, and R. S. Schwartz. 1983. Idiotype cross-reactions of monoclonal lupus autoantibodies. J. Exp. Med. 158:718-730.

15. Davidson, A., J. L. Preud'homme, A. Solomon, M-d. Chang, S. Beede, and B. Diamond. 1987. Idiotypic analysis of myeloma proteins: anti-DNA activity of monoclonal immunoglobulins bearing an SLE idiotype is more common in IgG than IgM antibodies. J. Immunol. 138:1515-1518.

16. Lafer, E. M., J. Rauch, C. Andrzejewski, D. Mudd, B. Furie, R. S. Schwartz, and B. D. Stollar. 1981. Polyspecific monoclonal lupus autoantibodies reactive with both polynucleotides and phospholipids. J. Exp. Med. 153:897-909.

17. Andrzejewski, C., J. Rauch, E. M. Lafer, B. D. Stollar, and R. S. Schwartz. 1981. Antigen binding diversity and idiotypic cross-reaction among hybridoma autoantibodies to DNA. J. Immunol. 126:226-231. 
18. Hoch, S., and J. Schwaber. 1987. Identification and sequence of the $V_{\mathbf{H}}$ gene elements encoding a human anti-DNA antibody. J. Immunol. 136:892-897.

19. Winfield, J. B., I. Faiferman, and D. Koffler. 1977. Avidity of anti-DNA antibodies in serum and IgG glomerular eluates in patients with systemic lupus erythematosus: association of high avidity antinative DNA antibody with glomerulonephritis. J. Clin. Invest. 59:9096.

20. Hahn, B. H. 1982. Characteristics of pathogenic subpopulations of antibodies to DNA. Arthritis Rheum. 25:747-752

21. Kubagawa, H., L. B. Vogler, J. D. Capra, M. E. Conrad, A. R. Lawton, and M. D. Cooper. 1979. Studies on the clonal origin of multiple myeloma. J. Exp. Med. 150:792-807.

22. Holm, G., H. Mellstedt, D. Pettersson, and P. Biberfeld. 1977. Idiotypic immunoglobulin studies on blood lymphocytes in human plasma cell myeloma. Immunol. Rev. 34:139-164.

23. Preud'homme, J. L., M. Klein, S. Lebourne, and M. Seligmann. 1977. Idiotype bearing and antigen binding receptors produced by blood T lymphocytes in a case of human myeloma. Eur. J. Immunol. 7:840-846.

24. Lee, K. H., F. Matsuda, T. Kinashi, M. Kodaira, and T. Honjo. 1987. A novel family of variable region genes of the human immunoglobulin heavy chain. J. Mol. Biol. 195:761-768.

25. Ralph, P., J. Prichard, and M. Cohn. 1975. Reticulum cell sarcoma: an effector cell in antibody-dependent cell mediated immunity. J. Immunol. 114:898-905.

26. Geliebter, J., R. Zeff, R. W. Melvold, and S. G. Nathenson. 1985. Mitotic recombination in germ cells generated two major histocompatibility complex mutant genes shown to be identical by RNA sequence analysis Kbm9 and Kbm6. Proc. Natl. Acad. Sci. USA. 83:3371-3375.

27. Berman, J. E., S. J. Mellis, R. Pollock, C. L. Smith, H. Suh, B Hanke, C. Kowal, L. Surti, L. Cantor, and F. W. Alt. 1988. Content and organization of the human Ig $V_{H}$ locus: definition of 3 new $V_{H}$ families and linkage to the Ig CH locus. EMBO (Eur. Mol. Biol. Organ.) J. 7:727-738.

28. Bentley, D. L., and T. H. Rabbitts. 1980. Human immunoglobulin variable region genes: DNA sequences of two $V_{K}$ genes and a pseudogene. Nature (Lond.). 288:730-733.
29. Zeff, R. A., S. S. Geier, and S. G. Nathenson. 1986. Molecular loss varients of the murine major histocompatibility complex: non-expression of $\mathrm{H}-2 \mathrm{~K}$ antigens associated with marked reduction in $\mathrm{H}-2 \mathrm{~K}$ mRNA as determined by oligonucleotide hybridization analysis. $J$. Immunol. 137:1366-1370.

30. Kodaira, M., T. Kinashi, T. Umemura, and F. Matsuda. 1986. Organization and evolution of variable region genes of the human immunoglobulin heavy chain. J. Mol. Biol. 190:529-541.

31. Ichihara, Y., H. Matsuoka, and Y. Kurosawa. 1988. Organization of human immunoglobulin heavy chain diversity gene loci. EMBO. (Eur. Mol. Biol. Organ.) J. 7:4141-4150.

32. Jaenichen, H. R., M. Peck, W. Landenmaier, N. Wildgruber, and H. G. Zachau, H. G. 1984. Composite human $V_{K}$ genes and $a$ model of their evolution. Nucleic Acids Res. 12:5249-5263.

33. Sharon, J., M. L. Gefter, L. S. Wysocki, and M. Margolies. 1989. Recurrent somatic mutations in mouse antibodies to azophenylarsonate increase affinity for hapten. J. Immunol. 142:596-601.

34. Diamond, B., and G. Solomon. 1983. A monoclonal antibody that recognizes anti-DNA antibodies in patients with systemic lupus. Ann. NY Acad. Sci. 418:379-385.

35. Davidson, A., J. Katz, A. Smith, and B. Diamond. 1987. Amino acid sequence analysis of light chains expressing an SLE associated idiotype. Arthritis Rheum. 30:S104. (Abstr.)

36. Liu, M. F., D. L. Robbins, S. S. Crowley, S. Sinha, F. Kozin, T. J. Kipps, D. A. Carson, and P. P. Chen. Characterization of four homologous $L$ chain variable region genes that are related to 6 BG.6 idiotype positive human rheumatoid factor light chains. J. Immunol. 142:688-694.

37. Seeman, N. C., J. M. Rosenberg, and A. Rich. 1976. Sequence specific recognition of double helical nucleic acids by proteins. Proc. Natl. Acad. Sci. USA. 73:804-808.

38. Eilat, D., D. M. Webster, and A. R. Rees. 1988. V region sequences of anti-DNA and anti-RNA autoantibodies from NZB/ NZW F1 mice. J. Immunol. 141:1745-1753.

39. Sanz, I., and J. D. Capra. 1988. The genetic origin of human autoantibodies. J. Immunol. 140:3283-3285.

40. Kocks, C., and K. Rajewsky. 1988. Stepwise intraclonal maturation of antibody affinity through somatic hypermutation. Proc. Natl. Acad. Sci. USA. 85:8206-8210. 